\title{
Back to the Cave: Cold, Hungry and Cruel? An epithet for the World Bank's neoliberal economy project
}

\author{
Maria Veronica G. Caparas \\ University of Alberta \\ caparas@ualberta.ca
}

The famine of 2008 is to last for a year, or so the gods of the North predict. Despite thick stimulus packages for basic services [such as education] that the leading empire releases in 2010 [aimed at achieving its 2015 millennium development goal of Education for All], restiveness reigns. Some gods opine that the famine is to be of a worse magnitude than that of the 1930s. These gods must have memory lapses to even compare the early $21^{\text {st }}$ century to that of the first half of the $20^{\text {th }}$ century. They must have forgotten that between the 1940s and 2000s, several gods have designed and charted development destinies for countries ravaged by the Second World War. Too many "divinely-inspired" cooks, in an iron chef show of one-upmanship, spoil the broth of development.

(From my academic reflection journal)

\begin{abstract}
In this article, I show that the World Bank, along with other international financial institutions, is the primary architect of neoliberal policy of privatizing the formation of higher education and the migration of skilled labour from the Global South to the Global North. The Bank, through development gurus and theories orchestrating the pro-North development agenda, systematically manoeuvres the neoliberalization of higher education and migrant labour from the 1980s to the late 2000s with the promise of democracy, equity, justice and prosperity. Despite massive doses of The Bank-prescribed neoliberal development pills, the majority of the world's population has yet to experience the promise. The Global South, through three selected countries that see the wisdom of wielding strong state roles in delivering social services, is able to partly parry the deadly sting of the 2008 global economic downturn. The South, immersed as it is in the North's development agenda as shown in selected literature, has become a doppelganger of the North. In determining the South's dynamic in service delivery, I turn to Habermas' communicative rationality that likewise brings to bear similarly framed thoughts as the yardstick of the South's critical voice against the North's continuing espousal of neoliberal policy. It is this critical voice that further cultivates people's micropolitics of beliefs, gender and language, and cries out "no" to The Bank-prescribed neoliberalized higher education and migrant labour - a prescription that leads to and simulates a "back-to-the-cave" circumstance.
\end{abstract}

Journal of Contemporary Issues in Education, 2011, 6(2), pp. 38-52

ISSN 1718-4770 @ 2011 University of Alberta

http://ejournals.library.ualberta.ca/index.php/JCIE 


\section{Introduction}

Hobbes once diagnosed life as "short, brutish and cruel" - a life reminiscent of cavemen's, and prescribed the Leviathan for humans to cope with life's shortness, brutishness and cruelty. The Hobbesian diagnosis came in the form of skirmishes that escalated from civil to global proportions, wreaking havoc everywhere. Soon, the world had to be reconstructed so humans could collaborate while enjoying freedom amidst a plethora of choices. As if in response to Hobbes' prescription of Leviathan, one mighty organization accorded upon itself the ability to wage bellum omnium contra omnes [i.e. "the war of all against all"] and acted like the Leviathan in a war against poverty, illiteracy and inequality. This organization came to be known as the World Bank (WB or The Bank). Together with other international financial institutions (IFIs) such as the Asian Development Bank (ADB), International Association of Universities (IAU), International Monetary Fund (IMF), United Nations Educational, Scientific and Cultural Organization (UNESCO), and World Trade Organization (WTO), The Bank implemented development theories that officials of IFIs themselves devised and supported in the name of poverty alleviation through literacy. These IFIs, through the years, spread the belief that human capital formation and highly-skilled labour migration should remain in the portfolio of capital speculators and industry entrepreneurs to achieve a given country's economic growth and development. I dissent. I present the cases of China, India and the Philippines where states' role in human capital formation and skilled labour migration has not been totally eclipsed by neoliberal posturing. These countries that exercised their freedom to choose their path to development registered economic growth (China vows to increase, 2007; India's budget propels growth, 2010; Japan assists Philippines, 2010) in the months immediately following the last quarter of 2008 despite The Bank's precarious journey back to the cave.

I sketch three main arguments around The Bank's failed neoliberal policy of privatization wrapped in the higher education and labour (HEAL) policies of The Bank's cohort of IFIs. I trace this neoliberal policy as naturally branching out of development theories of empowerment and participation, capacity-building and people-centered development, increased welfare and human development, and modernization. I present modernization theory, that pursued specialized division of labour for solidarity and an active state for human capital formation from the 1940s to the 1970s (Martinussen, 1997), as leading to neoliberal economic policy. Development thinkers, eventually, have systematically identified players and defined roles to eclipse state roles and to fit The Bank's neoliberal agenda in addressing preferential paths to economic and political hegemony.

Firstly, I argue that IFIs' HEAL policies, within the neoliberal economic policy (NEP) that showcase the systematic dominance of Western thoughts, are an extended effort of the West to prescribe modernization pills to "ailing" traditional societies. I show that, in this extended effort, main actors alternate between statist and mercantilist roles, simulating a "back to the cave" scenario where people competed for the prized catch, eventually engaged in "blood rites" (Ehrenreich, 1997) for power and politics, and gave vent to Hobbes' "life is short, brutish, and cruel."

Secondly, I focus on existing literature around three countries of the South, that is China, India and the Philippines to show the failed development project of The Bank-led IFIs' neoliberal agenda on HEAL in an internationalized Knowledge Economy (KE). I look into related literature and focus on how Chinese, Filipinos and Indians' beliefs, gender, and language 
make for micropolitics that expose the paradoxical effects of IFIs' neoliberal policy. Micropolitics refers to individuals or groups' use of formal and informal power in their attempt to impact or protect other people's behaviours and in their desire to attain dreams and goals thereby establishing political significance in a given situation (Blase, 1991).

Thirdly, using Habermas theory of communicative rationality and related theories of Habermas' disciples Benhabib and Fraser, I argue that individuals create and define their own sense of freedom despite external influences or forces. As they navigate their way through these forces, they interact with other individuals and subsequently get to stand by their choices. I argue that this dynamic likewise operates between the West and the East as the former tries to exert its theories of development on the latter that has the option to resist.

My use of the terms Global South and Global North depicts global inequality where the North continues to amass capital, such capital accumulation evocative of colonial histories and continuing colonial relations with the South. Additionally, the nature of the Group of 77 further clarifies the concept of Global South as based not on geographical polarization between north and south. G-77 comprises

the largest intergovernmental organization of developing states in the United Nations, which provides the means for the countries of the South to articulate and promote their collective economic interests and enhance their joint negotiating capacity on all major international economic issues within the United Nations system, and promote South-South cooperation for development. (About the Group of 77)

Seventy-seven developing countries that attended the first session of the United Nations Conference on Trade and Development in Geneva founded G-77 in 1964. China, India and the Philippines are G-77 states. Member countries have increased to 130, but the name G-77 is retained for historical significance.

I use West and East alternately with North and South to depict differences in beliefs and in degrees of development, respectively. I use NEP interchangeably with globalization which is the by-product of internationalized economic modifications that continue to witness the proliferation of labour divisions along with economic integrations worldwide (Morrow \& Torres, 2007). I combine HEAL to show that the formation of high human-social capital and migration of skilled labour is higher education's end in a global KE. In support of this claim, I turn to Bourdieu and Passeron (1990) who link educational demands with those of the labour market where higher education graduates may find themselves accorded appropriate or inappropriate rewards, and who depict learning institutions as the space for human capital formation. They look at schools as sites performing the technical and social functions of producing skills and capacities, and preserving power and privileges through networks, respectively. The scholastic implicitly social - function serves to reify the technical prerequisites for an occupation.

\section{The 1980s as the IFIs' reckoning period of neoliberal thrust}

In the early 1980s, IFIs - under The Bank's lead, became the prime advocates of neoliberalism (Giroux, 2008; Harrison \& Kachur, 1999; Peet \& Hartwick, 2009; Taylor, 2001) in higher education and labour. Neoliberalism, aka privatization of state-controlled services such as education and job creation, has its roots in Milton Friedman's massive indoctrination of global 
free trade on Pinochet's Chile in the 1970s; picked up by Britain's Prime Minister Thatcher in the late 1970s, neoliberalism became the policy regime of US President Reagan in the 1980s (Hardt \& Negri, 2009) and onto the $21^{\text {st }}$ century.

Two characteristics of neoliberalism impact IFIs' higher education and labour policies. The first characteristic frowns at the idea of a central agency orchestrating the market behaviour of individuals who, in general, have limited knowledge of the market. For neoliberalism to succeed in higher education and labour, based on the bible of neoliberal advocates, central planning has to be controlled or minimized. Weakened central planning, according to these neoliberal stewards, also precludes the central agency's fascist or totalitarian tendencies at market controls. The second characteristic of neoliberalism emphasizes the complexity of human-market relations, the imperfectability of the market, and the unintended consequences of both (e.g. credential inflation in higher education and lack of jobs for overly-trained labour).

What happened in the span of three decades, i.e., from the 1980s to 2008, was the proliferation of unbridled competition that resulted in a consumerist approach to higher education and to international labour trade. This was aggravated by the continuing overproduction of higher education graduates whose number failed to match the job market that barely had goods to offer.

Interestingly, The Bank-led IFIs have a unique composition of member-nations that vary in their economic approaches. Additionally, IFIs' structural adjustment programs (SAPs) or loan conditionalities on debtor countries offer touches of Keynesianism (Peet \& Hartwick, 2009) that respect the role of the state as crucial to a given country's economic make-up. It is just unfortunate that The Bank-led IFIs' leading majority shareholder, also influenced by various schools and thoughts of development, holds the key to the overwhelmingly neoliberal lock and drags its member-nations onto enriching the corporate driven market even more.

The nature of The Bank-led IFIs policies complements the formulation of development theories by leaders who have their own belief systems (Alacevich, 2009; Peet \& Hartwick, 2009) and are vested with self-serving interests verging on megalomania and the craft of oneupmanship. Rostow's idea of development came in the form of salvaging underdeveloped countries from the lair of communism in the 1950s up till the 1960s. Rostow blamed leaders of traditional societies for their failure to modernize. Rostow's words weighed too heavily, with his portfolio as director of the Policy Planning Staff of the U.S. State Department coupled with his economics background, as to be bypassed by The Bank. There was Rosenstein-Rodan in the 1940s who opposed WB's propensity to finance individual projects, and who vouched for state's role and intervention, industrialization of Third World Countries (TWCs), resettlement and emigration among trainable labour as key to development economics in TWCs. There was Hirschman in the 1950s who cannot work well with Currie on WB's monetary and fiscal policy. There was McNamara who ruled over WB much like he oversaw the US war moves on Vietnam as then U.S. Secretary of Defence. McNamara's WB from 1968 until 1981 focused on direct delivery of basic needs to inspire the poor towards having a sense of productivity and security. There was Clawson who - from 1981 until 1986, citing the case of Sub-Saharan Africa as a result of ineffective state controls on trade, led WB to neoliberal direction.

A quick look at the list of those who served as president of WB yields memberships in the US congress of ways and means committees or high-ranking services in state departments (Conable, 1986-1991), backgrounds in investment banking (Preston, 1991-1995), or chairmanships in large banking corporations (Wolfensohn, 1995-2005). To date, the shortestserving WB president is Paul Wolfowitz, leading The Bank from June 2005 up till June 2007, 
whose 24 years in government service came in the form of being a public servant, ambassador, and educator - a non-corporate background that may have served as a breather for The Bank's overwhelmingly mercantilist stance. Robert Zoellick has, from 2007, steered The Bank to a continuing neoliberal direction; however, his focus now is on accountability mechanisms embedded in SAPs among debtor-member countries. In HEAL, accountability comes in the forms of teaching-to-the-test, the formation of just-in-time-knowledge for the market, and the proliferation of labour temps among HE graduates who have no choice but to stay the course of the market.

Indeed, the years following WWII were characterized as modernization years where "backward" TWCs toed the structural changes that somewhat appealed to the North-Western line of development. Through the 1940s and the 1950s, The Bank led a development discourse characterized by loans-cum-structural adjustment programs such as industrialization, factory discipline, labour training (Escobar, 1995) meant to train the rest in the ways of the West. Peet and Hartwick (2009) see the 1960s to the 1970s as The Bank's years of delivering basic needs giving The Bank the face of global Keynesianism. Modernization clout extends in trickles to the 1970s (Martinussen, 1997) where "empowerment, participation, capacity-building," "increased welfare and human development" became IFIs' buzzwords in the 1960s to the 1970s, and the 1990s, respectively.

The last of these buzzwords gave birth to IFIs' Human Development Index (HDI), Poverty Reduction Strategy Programs (PRSPs) and Education Sector Strategy (ESS) all caught in the web of The Bank's NEP of development. Thinkers behind these development projects ensured that human development is sustainable, i.e., the potential of human capital and voice is tapped to the max. HDI likewise broached the image of people worldwide as having multiple choices and greater access to quality of life, and characterized as knowledgeable, better fed, healthy, active in their communities, and secure in their livelihoods within an enabling environment (HDR, 2009).

It is important to note that in contrast to IFIs' buzzwords, Bergeron (2008) critiques the 1999 ESS report touted as WB's anti-poverty agenda. It is actually a pro-growth agenda that focuses on increasing human capital for economic growth. It calls for privatizing and marketing of education - showing WB's preference for efficiency over a truly equitable and democratic growth. Ilon (2002) makes a similar critique as Bergeron's as she points out WB's unstated institutional role in the policy as a crisis of legitimacy. She laments the obvious lack of pronounced educational policy analysis in the document. Wickens and Sandlin (2007) likewise show how education policies of IFIs such as UNESCO, WB and IMF reflect the interests of rich industrialized countries.

Today's much-touted education for all (EFA) has its origin in UNESCO's birth in 1945. Founding member-nations signed a constitution expressing a belief "in full and equal opportunities for education for all." UNESCO claims that opportunities to realize EFA since then has become part of its mandate. It looks at "knowledge sharing, collaboration and capacity building" as important ingredients of speeded progress, and calls for increased coordination towards effective joint efforts and fully utilized efficient resources. It cites Article 26 of the 1948 Universal Declaration of Human Rights,

Everyone has the right to education [and works at] giving everyone the chance to learn and benefit from basic education - not as an accident of circumstance, nor as a privilege, but as a RIGHT. (Ten things about EFA) 
UNESCO's focus on basic literacy gradates to secondary education and onto HE as it works with civil society that acts as key partner in campaigning for more funding and in looking for other learning avenues for the majority of the world's population.

UNESCO acknowledges that it has yet to see through 1) the education in basic literacy of approximately 75 million children and an estimated 776 million adults (16\% of the world's population); 2) the dropping out of millions of students not gaining basic literacy and numeracy skills; 3) a severe teacher shortage; 4) education benefiting all; 5) low opportunities for adolescents and out-of-school youth; 6) the obstacles of poverty, marginalization, disadvantage, geographic isolation, gender, language and ethnicity; and 7) the improvement of school and education system management. Its HE arm, International Association of Universities (IAU) referred to as UNESCO-based worldwide association of higher education institutions, was founded in 1950. IAU aims at reflecting, collaborating, and acting with international, regional and national institutions and organisations from some 150 countries on common concerns in higher education (IAU policy statement, 2008). IAU supports 1) higher learning across race, gender, language, class, age, religion, beliefs; 2) equitable access and academic excellence for quality HE; 3) development of national and institutional policies to address academic, financial and personal barriers among HE learners; and 4) international mobility, exchanges and crossborder education activities, inter alia.

Ostensibly pro-rich in their policy formulation, IFIs come across as preparing human capital and skilled labour for viable roles as commodities in the global market. That human capital formation and skilled labour migration are significant to economic growth and to elimination of gender-related disparities get eclipsed. A closer reading of WB's take on HEAL in its 2007 document may be instructive,

[WB] recognizes that universal, high quality education reduces poverty and inequality and sustains economic growth. Such education is also fundamental for the construction of democratic societies and globally competitive economies. It improves people's skills, which, in turn, improve their incomes... [and facilitates women's inclusion and] participation in economic development. (The World Bank, pp. 149-159)

What is not stated is how human capital and skilled labour formation among the impoverished could take place. The Bank does not talk about the role of entrepreneurs in funding human capital formation and skilled labour migration or the SAPs that it imposes on poor countries as part of The Bank's neoliberal agenda. The Bank's SAPs deter poor countries from hitting their economic growth potential. While The Bank views globalization as the impetus for international economic growth and poverty reduction, The Bank also acknowledges the hot debates and contestations around it, i.e., globalization has seen massive inequality (The World Bank, 2007). Despite such acknowledgment, The Bank still fails to expose its pro-North agenda of development. What gets highlighted is that, in The Bank's efforts at pulling up poor countries, the promise of democracy, equity, justice, and prosperity has to be the collateral damage.

Paradoxically, advocates of neoliberalism who were dreaming of delivering the promise end up formulating HEAL policies that are pro-elite, and that favour the formation of human capital and migration of skilled labour among those equally privileged in target countries of development. NEP advocates, knowingly or unknowingly, manoeuvre a life for the minority of 
the world's population that smacks of individualism, greed, competition, war for power, and a culture of violence - a life similar to cavemen's. In the process, NEP thinkers also become cave people, mired in the cycle of NEP culture. Their caves though sit within high-powered technological apparatus where further formation of human capital and migration of skilled labour get monitored and surveilled to suit Western designs of continued domination. HEAL policies morph human capital and skilled labour as commodities in a global KE, and facilitate human capital and skilled labour's global mobility resulting in brain drain among source countries and brain gain in host countries (Spring, 2009).

The 2008 major bail-out of private entrepreneurs that marked the start of global recession apparently disproves reliance on too much individual freedom and on the belief that central planning should be limited only to the rule of law and away from the economic sphere (Peet \& Hartwick, 2009). The state, using public funds, bailed out the market from its freedom vice. This somewhat cushioned the economy from the ill effects of mercanticide [market's intended or unintended suicide, in my sense]. However, more job cuts and other forms of financial displacement continue to haunt the majority of the world's population.

Despite 2008 being ominous, NEP advocates insist on allowing Adam Smith's invisible hand in guiding the market. Indeed, the mind and the ethos of markets focus mainly on profits quite a zero-sum game. It is now 2011, and The Bank's neoliberal policy regime has yet to deliver the promise of democracy, equity, justice, and prosperity.

\section{Containing the market within human-social-labour capital bounds}

Human capital and skilled labour formation in China, India and the Philippines has become a combination of Western and Eastern influences - fodder to the globalizing trends of KE. These three countries, among the original 44 member-nations of WB on its inception in 1944, became members of subsequent IFIs, and have since been bound by IFIs' HEAL policies. Despite the global economic slump that began in 2008, these Asian countries seem to bounce rapidly as evident in ADB's forecast "that the emerging Asia has grown 4.5 percent in 2009 and the region's economy is set to continue the rebound to reach 6.6 percent in 2009, higher than the 6.1 percent growth registered in 2008" (Asia recovers fast, 2010).

Is this quick recovery due to these Asian countries' reluctance to go fully neoliberal in their policies? One proof of China's strong state is obvious in its budget allocation for education in 2007 that hit 646.1 billion yuan (US\$85 billion), 105.3 billion yuan (US\$13.9 billion) more than that of the previous year, up $19.5 \%$ year-on-year, higher than the $15.7 \%$ growth rate of China's fiscal budget (China vows to increase, 2007). India, on the other hand, also boasts a robust economy as reflected in its 2010-2011 budget. Education is projected to get generous allocation (India's budget propels growth, 2010). The Philippines, meanwhile, pegged a growth rate close to five percent over the past five years but the poverty level remains at 30\%" (Japan assists Philippines, 2010). What keeps the Philippine economy from a nosedive is the bulk of remittances it gets from human capital and skilled labour in international worksites. In these three countries, educational Keynesianism - i.e., the state's support for and delivery of education services remains moderate, if not strong. It is lack of or too weak a labour Keynesianism - i.e., the state's creation of jobs to meet the high number of university graduates, that results in migration of skilled labour from the South to the North where neoliberal precepts abound.

There are issues that countries in the South grapple with as they get entrenched within the North's neoliberal policy on HEAL. Bacon (2008) cites human capital and skilled labour cases 
from the South [including China, India and the Philippines] that migrate to the Global North. With this movement, human capital and skilled labour get politically exploited, deprived of rights to substantial wages and work conditions, denied of permanent resident qualifications and citizenship rights, and eventually deported once the jobs they hold are done. Simply put, human capital and skilled labour are highly utilized by the North to exploit the policies of the South (e.g. labour export policy) that are actually merged with oppressive trade agreements dictated by IFIs such as WTO to which member nations are forced to comply. Human capital and skilled labour, no doubt, become pawns in an economically-entrenched arrangement that greatly benefits the North - a continuing colonial tragedy indeed.

The continued loss of engineers recruited by Silicon Valley contributes to brain drain in India, China, and the Philippines - the source countries for most workers with HI-B visa, a nonimmigrant visa that allows a US company to employ a foreign individual for a maximum of six years. Bacon writes about the views of Mittal, an Indian-born co-director of the Oakland Institute which is a non-profit research and advocacy institute in Oakland, California,

These [recruitment] programs are selling our human potential. Our educational system produces highly skilled workers, who then leave to become the working poor in America, while breaking down our ability to industrialize our own country. We wind up subsidizing US industry. (Bacon, 2008, p. 238)

Blau et al. (2010) present the cases of China and India that, while registering considerable growth in per capita income simultaneous with the creation of modern cities, show rural populations in dire need of economic facelift. Both countries are likewise challenged with preferential thrusts for sons expected to perform filial duties and obligations. Growing research patterns and trends, however, show that mothers with high economic resources such as better jobs and higher educational attainment are able to spend for their children - either sons or daughters. This benefits children on the whole. The improvement on women's status - from cultural to economic factors - saw solid affirmation in the United Nations Fourth World Conference on Women in Beijing where a concrete plan for women's education as key to their progress was set up. This, however, is based on anticipatory benefits such as educated women's greater potential to penetrate the labour force and raise their income-capacity levels, greater ability to reduce their fertility, higher capacity to participate in health-consciousness raising among household members, etc. This becomes very problematic as the notion of women's development is ostensibly Western-defined. Changing family structures and work roles likewise affect posterity negatively. There are increasing single parent/mother households where young children are left to the care of day care centre staff, and do not fare as well as those in complete family households. Family values are then set aside in the name of development.

Meanwhile, Abdi and Kapoor (2009) present the contradiction behind neoliberal globalization as having led to social division, cultural fragmentation, and lacking essential ingredients in developing human capital. They also point out the paradox of globalization in China where 300 million Chinese live in poverty while only a few benefit, and in India where rural folks are displaced to accommodate multinational corporations out to extract cheap labour among highly-skilled people.

$\mathrm{Li}$ and McHale (2009) did a study, covering 212 countries and territories in 1996-2007, on how a country's human capital impacts its institutions via various channels (e.g. how global mobility would likely affect a country's institutional development). They used WB datasets on 
labour mobility and economic-political institutions with six dimensions of institutions: Voice and Accountability, Political Stability and absence of Violence/Terrorism, Government Effectiveness, Regulatory Quality, Rule of Law and Control of Corruption, and found larger emigrant human capital to be linked with higher quality political institutions that have lower quality economic institutions. Man (2004), on the other hand, shows the declining pull of the North among Chinese human capital and skilled labour from financially-endowed Hong Kong. She attributes this to the negative image of the North where cases of unemployment and underemployment abound.

Murphy and Johnson (2009), on the other hand, cite literature on the tensions in China over policies in the areas of education financing, curriculum and pedagogy where local resources, local innovation, flexibility and initiative may be maximized under decentralized management. China's education history may also explain how maximization of local resources becomes feasible. China's present educational system is a product of three major influences: Confucian philosophy that reproduced the classics in civil service examinations, Deweyan progressivism that became highly influential from the 1920s to the 1940s and Mao's socialist proletarianism that began in 1917 (Guo, 2009). All three influences rally for education's stimulus leading to social change and the formation of creative, analytical, critical and pro-worker students.

In India, Gandhi sought and propagated the principle of simplicity to counter the effects of modernity and to eventually call for independence from British colonization. This was an act aimed at nationalism but it led to Indians' espousal of development and industrialization that assisted them in establishing identity, power and dignity towards equality with former colonizers. Indigenous leaders and scholars, however, see this move towards equality as more of a mockery of independence from colonial rule as it as a form of "cultural genocide" or "assimilation" (Niezen, 2003, p. 17) into the fold of the colonizers. This mockery of independence stretches over to India's reign in information and communication technology (ICT). Its ICT cluster in Bangalore is often referred to as the Silicon Valley of the East, and boasts of having more than 1,500 information technology firms. Bangalore is also the site for wholly-owned subsidiaries of multinational corporations such as Motorola, Texas Instruments, and Hewlett-Packard with a range of services, including customer software application development, maintenance, facility management, and training (Basant, 2008).

In the Philippines, educational policymakers lament the country's highly politicized setting and inadequate resources as contributing to the decline in HE quality. Once the onlyEnglish-speaking country in Asia powered by American colonial influence, the country is now losing its edge in English education. Santiago (2005) suggests that the Commission on Higher Education should be aggressive in campaigning for cross-border education that would push Philippine HE towards constructive competition with Asian HE institutions. Santiago's suggestion re-echoes that of Gonzalez's (2004) who sees the adoption of The Bank-led neoliberal privatizing of $\mathrm{HE}$ as essential in meeting the demands of the $21^{\text {st }}$ century - a requisite for developing economies. Gonzalez and Santiago's stand may be a result of too much reliance on IFIs' prescriptions that impress upon the Filipino psyche the significance of education in economic and social mobility. 


\section{Critiquing The Bank's modernization and neoliberal policy of privatization}

The IFIs' modernization and neoliberal economic pills for the rest of the world failed to cure the continuing chaos, inequality, injustice, and poverty. It is the task of the world's majority - the so called margins or the poor or the have-nots of the Global South - to bring their case to the table.

Habermas' (1987[1981]) theory of communicative rationality shows individuals as critical agents of their destiny,actively participating in achieving and effecting social changes. Cognizant of the primacy of democratic action in addressing crises, Habermas' (1981/1987) theory emphasizes the marriage of theory with praxis, engenders self-reflexivity, inspires democratic consultations and renewal, advances conscious engagement with the transformative process of analytical work, and advocates emancipatory social movements in capitalist societies. Habermas' influence around the notion of communicative rationality extends to Benhabib's (1992) take on humans' universal sense of judgment. Universalism in morality

- commits to every individual's self-worth and self-dignity vis-à-vis that individual's humanity;

- respects needs, interests and points of view;

- cognizant of everyone's standpoint through specific and detailed moral deliberations;

- engages in practical discourses in order to establish valid intersubjective norms and rules of action; and

- conscious of the constraints of value judgments that may be just, benevolent, or morally relevant.

Benhabib's universalism, in support of Habermas' communicative rationality, calls for providing an avenue for consultation as well as advocates participatory democracy. The voice of the majority leads various stakeholders towards an action that exposes the North's continuing exploitation of the world's poor (e.g. The Bank's focus on neoliberalized education legitimizes IFIs' overproduction of human capital; credential inflation and lack of jobs for overqualified professionals overshadows literacy development and marketability of the world's majority).

Equally Habermasian in perspective are Benhabib's (2002) advocacy of the politics of complex cultural dialogue and Fraser's defence of the politics of recognition. The latter recognizes the equally complex and intricate public self- and other-identification in relation to social reality. Benhabib's (2002) valuation of individuals' territorial freedom may be instructive - such freedom bounded by and subjected to changing situations. With globalization, according to Benhabib (2002), the state's administrative functions have been found wanting in influencing decision and outcomes, and the state's redistributive role has likewise declined resulting in increasing volatility and fragmentation of collective cultural identities. Additionally, she states that the challenge of globalization is in fundamentalism that advocates dreams of purity that are doomed to failure and that would inevitably cast human suffering, instability and fear. This brings to mind what little the state has to say to the self that has learned to navigate its liberty through knowledge and appreciation of moral principles that are at least culture-bound and at most market-dictated.

While the explications of Habermasian disciples Benhabib and Fraser highlight the centrality of human dispositions and roles that play out towards better individual plight, the state's role in giving people their voices and in recognizing the complexity of the market 
becomes indispensable. The neoliberal economic regime limits other forms of freedom and refuses to heed people's voices.

The formation of human capital in China, India and the Philippines and migration of skilled labour from these three countries to the North have turned into what may be ascribed, in conjunction with Habermas' theory of communicative action, to Fraser's (2007) "transnational public spheres" - an inevitable result of historical transmutations and constellations. It appears that HEAL issues have taken on the countenance of a level playing field between the North and the South where players from either pole continue to engage in a tug-of-war of sorts, each set of players engendered by their respective beliefs, entitlements, identities, privileges, and rights yet haunted by the irreversible imprints of histories. One set of players - that of the Global South, seemingly guided by the Habermasian prompt of communicative rationality, continues to taunt the other set of players with failure to live or abide by the principles of genuine democracy, equity, justice and prosperity.

\section{Conclusion}

I articulated three arguments to show how the Bank-led IFIs created a policy regime that hardly served as a panacea for the Hobbesian diagnosis.

The first argument showed the systematic dominance of Western thoughts through The Bank-led IFIs' pills of development administered on "ailing" traditional societies. Societies were transformed from state-governed to market-dictated entities, radicalizing competition and prompting people to engage in blood rites as they continually hunt for the prized catch - the neoliberal promise of democracy, equity, peace and prosperity. Done by self-interested technocrats and enterprising leaders of IFIs such as ADB, IAU, IMF, UN, UNESCO, and WB,

the neoliberal transformation of state responsibilities [i.e., formation of human capital and creation of labour] into a market-sensitive package has failed.

The second argument proved, through existing literature, that micropolitics in people's beliefs, gender, and language are edifying tools of agency that accord economic, social and political power among people from China, India and the Philippines within an internationalized Knowledge Economy. Given that people do not have perfect knowledge of the market and people in traditional societies become pawns to IFIs' modernization projects, people's choices may be faulty. They are forced to act based on IFIs' brand of development that gets trickled through their respective state policies. They may live the lessons of their choice or engage in communicative action to quell wrong choices. Communicative action through constant lobbying in legislative assemblies, lightning rallies, mass protests, media exposure, and organized demonstrations remains an effective tool in discrediting The Bank-led IFIs and in unravelling the causes of social inequalities.

Finally, that communicative action requires the spreading of significant information about issues that make the promise of democracy, equity, peace and prosperity elusive cannot be overemphasized. In my present inquiry on development as a function of the North's prescribed theories of modernization-up-until-neoliberal economic policy of globalization, critical theorists Habermas and his disciples show the significance of morally informed people navigating their way to a life of democracy, equity, justice and prosperity. Together, these thinkers demonstrate that people could pursue their interests and reflect on the rightness of their choice once properly equipped and accordingly governed. It is instructive that the East weave the lessons of Western colonization into a tapestry of concrete actions that would expose and dismantle continuing 
messages of Western control and domination. The East will benefit from continually engaging in social-historical analyses of how Western-dictated development prescriptions manipulate a lopsided zero-sum power field. As Massey’s (1993) “power geometry” shows,

The potential benefits of time-space compression are not available equally to all, and for some groups, growing interactions with people and places from the other side of the world are not necessarily desirable. (in Willis, 2005, p. 174)

This power geometry is best exemplified in the North's handling of internationalized KE among Asian high human capital and skilled labour as Abdi and Kapoor (2009), Bacon (2008), Blau et al. (2010), Harrison and Kachur (1999), Li and McHale (2009), Man (2004), Taylor (2001), and Wickens and Sandlin (2007) articulated. Policymakers of both North and South need to open avenues to enable people's micropolitics of beliefs, gender, and language to negotiate the formulation of HEAL policies that address the formation of high human capital and skilled labour according to the uniqueness of their respective cultures, histories, traditions and values. I concur with Benhabib (1986) when she states, "The perspective of the generalized other urges us to respect differences, individual life-histories and concrete needs" (p. 351). To date, the Bankled IFIs have yet to respect the complexity and uniqueness of Chinese, Indian and Filipinos' histories within the context of a global knowledge economy, and have unwittingly dragged themselves - along with the rest of the world - back to the cave. 


\section{References}

Abdi, A. \& Kapoor, D. (2009). Global perspectives on adult education: An introduction. In A. Abdi \& D. Kapoor (Eds.), Global perspectives on adult education. NY: Palgrave Macmillan.

Alacevich, M. (2009). The political economy of the World Bank: The early years. Stanford University Press and The World Bank.

Asia recovers fast but not likely to reach pre-crisis highs. (2010, January 14). Retrieved from http://english.people.com.cn/90001/90778/90858/90863/6869241.html

Bacon, D. (2008). Illegal people: How globalization creates migration and criminalizes immigrants. Boston, Massachusetts: Beacon Press.

Basant, R. (2008). Bangalore cluster: Evolution, growth, and challenges. In S. Yusuf, K. Nabeshima \& S. Yamashita (Eds.), Growing industrial clusters in Asia: Serendipity and science. Herndon, VA, USA: The World Bank. Retrieved from http://site.ebrary.com/lib/ualberta/Doc?id=10231573\&ppg=169

Benhabib, S. (1986). Critique, norm, and utopia: A study of the foundations of critical theory. New York: Columbia University Press.

Benhabib, S. (1992). Situating the self: Gender, community and postmodernism in contemporary ethics. Great Britain: Polity Press.

Benhabib, S. (2002). The claims of culture: Equality and diversity in the global era. Princeton University Press.

Bergeron, S. (2008). Shape-shifting neoliberalism and World Bank education policy: A response to Steven Klees. Globalisation, Societies and Education 6, 349-353. doi: 10.1080/14767720802506680

Blase, J. (1991). The politics of life in schools: Power, conflict, and cooperation. Thousand Oaks, CA: Sage.

Blau, F., Ferber, M. \& Winkler, A. (2010). The economics of women, men, and work. Sixth edition. Prentice Hall.

Bourdieu, P. \& Passeron, J.C. (1990). Reproduction in education, society and culture $\left(2^{\text {nd }}\right.$ ed.). (Nice, R., Trans.). (Original work published 1970). SAGE Publications Ltd.

China vows to increase input into education in coming years. (2007, September 10). Xinhua. Retrieved from http://english.people.com.cn/90001/90781/6258697.html

Ehrenreich, B. (1997). Blood rites: Origins and history of the passions of war. New York: Henry Holt and Company, LLC.

Escobar, A. (1995). Encountering development: The making and unmaking of the Third World. Princeton University Press.

Financial crisis endangers children's education worldwide: UNESCO. (2010, January 20). Retrieved from http://english.people.com.cn/90001/90782/6874226.html

Fraser, N. (2007). Transnationalizing the public sphere: On the legitimacy and efficacy of public opinion in a postWestphalian world. In S. Benhabib, I. Shapiro \& D. Petranović. (Eds.). Identities, affiliations, and allegiances. Cambridge University Press.

Giroux, H. (2008). Against the terror of neoliberalism: Politics beyond the age of greed. Paradigm Publishers.

Gonzalez, A. (2004). The Philippines: Past, present and future dimensions of higher education. In P. Altbach \& T. Umakoshi. (Eds.). Asian universities: Historical perspectives and contemporary challenges. Baltimore, Maryland: The Johns Hopkins University Press. 
Guo, S. (2009). East meets west, Dewey meets Confucius and Mao: A philosophical analysis of adult education in China. In A. Abdi \& D. Kapoor. (Eds.), Global perspectives on adult education. NY: PALGRAVE MACMILLAN

Habermas, J. (1987 [1981]). The theory of communicative action (Vol. 2). (T. McCarthy, Trans.). Boston: Beacon Press.

Hardt, M. \& Negri, A. (2009). Commonwealth. Cambridge, Massachusetts: The Belknap Press of Harvard University Press.

Harrison, T. \& Kachur, J. (Eds.). (1999). Contested classrooms: Education, globalization and democracy in Alberta. University of Alberta Press.

Human Development Report. (2009). United Nations Development Program. Retrieved from http://hdr.undp.org/en/humandev/

Ilon, L. (2002). Agent of global markets or agent of the poor? The World Bank's education sector strategy paper. International Journal of Educational Development 22, 475-482. pii: S07 38 -0593(02)00007-X

India's budget propels growth, puts recession in past, says USIBC. (2010, February 26). Retrieved from http://finance.yahoo.com/news/Indias-Budget-Propels-Growth-bw948107092.html? $\mathrm{x}=0 \& . \mathrm{v}=1$

International Association of Universities General Information. Retrieved from http://www.iau-aiu.net/association/index.html

International Association of Universities Policy Statement. (July 2008). Retrieved from http://www.iau-aiu.net/access_he/pdf/Access_Statement_July_2008.pdf

Japan to assist Philippines in logistics infrastructure upgrading. (2010, January 1). Logistics Insight Asia. Retrieved from http://www.logasiamag.com/article-1758japantoassistphilippinesinlogisticsinfrastructureupgrading-LogisticsAsia.html

Li, X. \& McHale, J. (2009). Emigrants and institutions. Retrieved from http://siteresources.worldbank.org/INTINTERNATIONAL/Resources/15728461253029981787/6437326-1253030145620/Li_McHale.pdf

Man, G. (2004). Gender, work and migration: Deskilling Chinese immigrant women in Canada. Women's Studies International Forum, 27, 135- 148. Retrieved from http://www.sciencedirect.com/science?_ob=ArticleURL\&_udi=B6VBD-4CTTJ9B$1 \&$ user $=10 \& \_r d o c=1 \& \_f m t=\& \_$orig $=$search $\& \_s o r t=d \& \_$docanchor $=\&$ view $=c \& \_$acct $=$

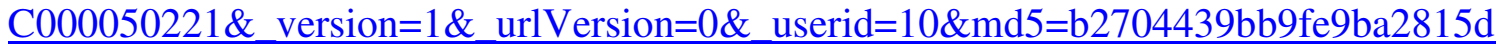
dc320eb761a

Martinussen, J. (1997). Society, state \& market: A guide to competing theories of development. London and New Jersey: Zed Books Ltd.

Morrow, R. \& Torres, C. (2007). The state, social movements, and educational reform. In R. Arnove \& C. Torres (Eds.), Comparative education: The dialectic of the Global and the local ( $3^{\text {rd }}$ ed.) (pp. 79-100). USA: Rowman \& Littlefield Publishers, Inc.

Murphy, R. \& Johnson, D. (2009). Editorial - Education and development in China Institutions, curriculum and society. International Journal of Educational Development 29, 447-453. doi:10.1016/j.ijedudev.2009.06.003

Niezen, R. (2003). “A new global phenomenon?" In The origins of indigenism: Human rights and the politics of identity. (pp. 1-28). Berkeley: University of California Press.

Peet, R. \& Hartwick, E. (2009). Theories of development: Contentions, arguments, alternatives. (Second edition). London and New York: The Guilford Press.

Santiago, A. (2005). Cross-border transactions in higher education: Philippine competitiveness. 
Philippine Institute for Development Studies. Retrieved from http://serp-p.pids.gov.ph/details.php3?tid=3730

Spring, J. (2009). Globalization of education: An introduction. New York: Routledge Taylor, A. (2001). The politics of educational reform in Alberta. University of Toronto Press.

Ten things you need to know about education for all. UNESCO. Retrieved from http://www.unesco.org/en/efa/the-efa-movement/10-things-to-know-about-efa/

The World Bank. (2007). A guide to The World Bank. Second Edition. Washington, D.C.: The World Bank.

US H1B Visa. Workpermit.com retrieved from http://www.workpermit.com/us/us_h1b.htm)

Wickens, C. \& Sandlin, J. (2007). Literacy for what? Literacy for whom? The politics of literacy education and neocolonialism in UNESCO- and World Bank-sponsored literacy programs. Adult Education Quarterly 57(4), 275-292. doi: 10.1177/0741713607302364

Willis, K. (2005). Theories and practices of development. London and New York: Routledge. 